\title{
Gladius and Statolith as Tools for Age and Growth Studies of the Squid Loligo plei (Teuthida: Loliginidae) off Southern Brazil
}

\author{
José Angel Alvarez Perez ${ }^{1 *}$, Daniela Cordella de Aguiar and João Antônio Teixeira dos \\ Santos \\ Centro de Ciências Tecnológicas da Terra e do Mar; Universidade do Vale do Itajaí; C. P. 360; \\ angel.perez@univali.br; 88302-202; Itajaí - SC - Brasil
}

\begin{abstract}
Statolith and gladius were investigated for their suitability as tools for age and growth studies in the loliginid squid Loligo plei off southern Brazil. Statoliths when polished, revealed a series of concentric increments deposited around a nucleus. Consistent increment counts covered the squid's entire life-time and could be considered suitable for individual age estimation. Growth increments were observed on the dorsal surface as delimited by consecutive marks formed during low growth periods. Because early growth was masked during chitin deposition, total increment counts underestimated individual age. Gladius growth was highly correlated with somatic growth, and gladius increments could be used to reconstruct individual growth histories. Both statolith and gladius increments were deposited with the same, possibly daily, periodicity. It could be inferred that L. plei off southern Brazil might live up to around nine months of age.
\end{abstract}

Key words: Cephalopods, statolith, gladius, age, Loligo plei, growth

\section{INTRODUCTION}

Coastal loliginid squids, as most known cephalopods, are short-lived organisms that concentrate individual reproductive effort in one terminal spawning event that precedes death. Population stability is dependent on the reproductive success of each generation, and recruitment, the process that links successive generations, seems to regulate population abundance and its temporal variations (O'Dor, 1998). The risks involved in such a peculiar life cycle are partially attenuated by an extended spawning period which results in the formation of within-generations "micro-cohorts" that originate in different times of the year and experience a variety of environmentally-determined growth and survival conditions (Caddy, 1991; Boyle and Boletzky, 1996; O’Dor, 1998). As a consequence, lolignid squid concentrations exhibit complex population structures, which are normally composed of individuals with different biological attributes such as growth rates, size- and age-atmaturity (Collins et al., 1999; Moreno et al., 2002).

The application of conventional stock assessment methods to squid stocks have been limited by these population features and often produced misleading results. One typical example is the estimation of squid growth from models fitted to periodic size frequency distributions, which tend

${ }^{*}$ Author for correspondence 
to underestimate growth rates by defining unrealistic modal sizes that mask individual growth (Caddy, 1991; Hatfield, 1991).

During the past 30 years, ageing methods, as derived from the interpretation of growth increments in the microstructure of squid hard structures such as statoliths and gladius, have elucidated much of such limitations, providing reliable estimates of age in days and backcalculated daily growth rates (reviewed by Rodhouse and Hatfield, 1990; Jereb et al., 1991; Jackson, 1994). Collective and individual growth, cohort analysis and life-history reconstruction have been successfully obtained for several squid species and have allowed comprehensive population processes to be finally resolved (Caddy, 1991; Jackson, 1994; Arkhipkin and Perez, 1998).

Analogous to fish otoliths, statoliths are paired calcified structures located inside cephalopod's equilibrium organ, the statocist. When polished, their exposed microstructure reveals a series of concentric increments which have been frequently shown to be deposited at approximately a $24 \mathrm{~h}$ cycle (Jackson, 1994; Lipinski, 1993). Their interpretation have allowed individual squid age to be estimated and substantial size-at-age data to be produced and used principally for squid growth model fitting procedures (Jackson, 1994). The gladius is the internal uncalcified chitinous shell present in squids and sepiolids. Periodic growth increments have been identified in all three shell layers (ostracum, hypostracum and periostracum) and shown to be suitable for age determination and principally to reconstruct squid individual growth (Arkhipkin and Bizikov, 1991; Bizikov, 1991; Jackson et al., 1993; Perez et al., 1996; Perez and O`Dor, 1998, 2000; Arkhipkin and Perez, 1998). Both structures have been used in loliginid squid age and growth studies (Jackson, 1990; Jackson et al., 1993; Balgos and Pauly, 1998 and others).

Loligo plei has sustained the most important coastal cephalopod fishery off southern Brazil (Perez, 2000). Population biology and reproductive studies conducted on squid concentrations vulnerable to both inshore and offshore fishery have raised population structure hypotheses relevant to the assessment and management of the seasonal fishery (Perez et al., 2002). The evaluation of such hypotheses, however, demands a comprehensive analysis on the stock age structure and growth attributes which can only be achieved from the development of reliable ageing techniques (Jackson and Forsythe, 2002). This work evaluated the suitability of the statolith and gladius of $L$. plei caught off southern Brazil for age and growth studies.

\section{MATERIAL AND METHODS}

A total of 109 males ranging from 35 to $342 \mathrm{~mm}$ mantle length (ML) $(1.6-308.0 \mathrm{~g}$ wet weight) and 176 females ranging from 61 to $221 \mathrm{~mm}$ ML (9.8 $-273.0 \mathrm{~g}$ wet weight) were obtained from the trawl fishery landings between May 1995 and May 1997, as part of a daily fishery sampling program developed for the industrial fishing in Santa Catarina State, Southern Brazil (Perez et al., 2002). The mantle length and the total wet body weight of each individual were recorded in the laboratory to the nearest $\mathrm{mm}$ and $\mathrm{g}$, respectively, and statoliths and the gladius were extracted and stored in ethanol (70\%) and formalin (4\%) respectively.

Statoliths were prepared following the general methods (Jereb et al., 1991). Each statolith was mounted on a glass slide and had the convex surface ground in the sagittal plane. Grounding was conducted with a series of $400,12,8,6 \mu \mathrm{m}$ $3 \mathrm{M}^{\circledR}$ grinding paper until the obtained surface maximized growth ring visualization. Ground surfaces were examined under a light microscope and displayed on a monitor screen where images were enhanced with the aid of an image analysis system (Image-Pro Plus ${ }^{\mathrm{TM}}$, Media Cybernetics ${ }^{\circledR}$ ). Statoliths had their larger axis measured under 6.7X magnification (SL, Fig. 1) and grow rings were counted along the axis of maximum growth under 1000X magnification.

Gladii were prepared and read using the relative growth technique proposed by Bizikov (1991). Each gladius had the formalin rinsed in water and was measured for total length (GL) and marked at $10-\mathrm{mm}$ intervals from the posterior (fins) to the anterior end (head) (Fig. 1). The dorsal surface of the gladius was then examined under a dissecting microscope at 20-30X using a combination of incident and transmitted light to optimise the visualization of growth increments. Growth increments were counted per gladius length interval from the anterior (head) to the posterior (fins) end until increments were no longer visible (Fig. 1). The mean spacing between growth increments (mean growth increment in 
millimetres) was calculated by dividing $10 \mathrm{~mm}$ by the number of growth increments counted in a gladius length interval.

The consistency of both gladius and statolith increment counts was assessed by comparing three independent counts of 30 selected squids made by a single reader. The total number of increments counted on the three occasions in each statolith and in a fixed proportion of the gladius length were compared by (a) the average percent error (APE; Beamish and Fournier, 1981) and (b) the coefficient of variation (CV, Chang, 1982). APE

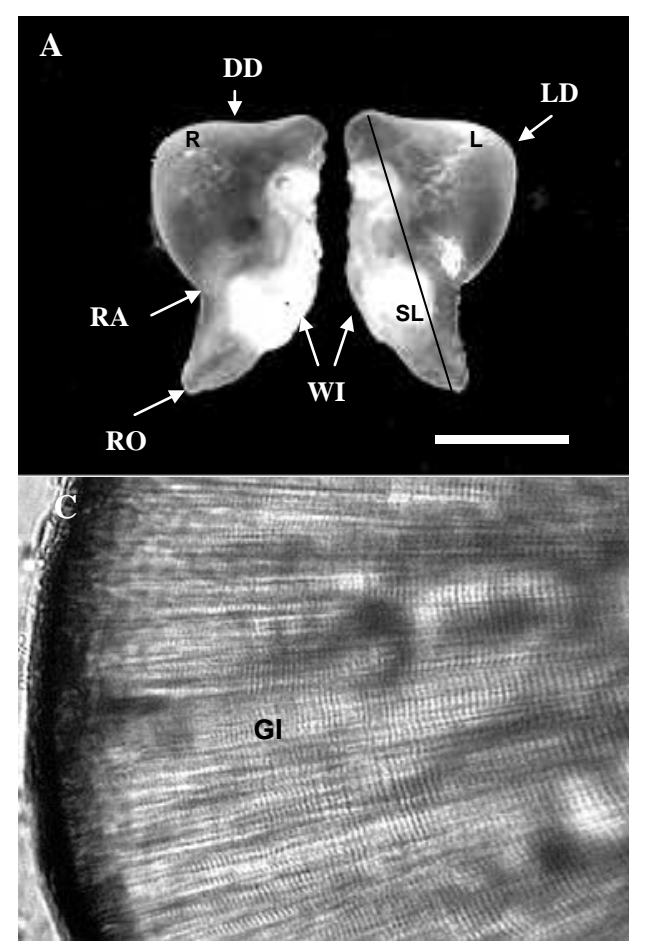

expressed the percentual deviation of each of the three counts from the mean count. CV expressed the standard deviation as a percentage of the mean count. Direct comparisons between statolith counts were also conducted through linear regression analysis (Zar, 1984). In a total of 98 squids, the number of statolith rings was compared to the number gladius increments deposited anterior to the initial $70 \mathrm{~mm}$ of the gladius length. A regression line was then fitted to the relationship between both counts and their deposition rates were compared using a $t$ test (Ho: slope $=1)$.
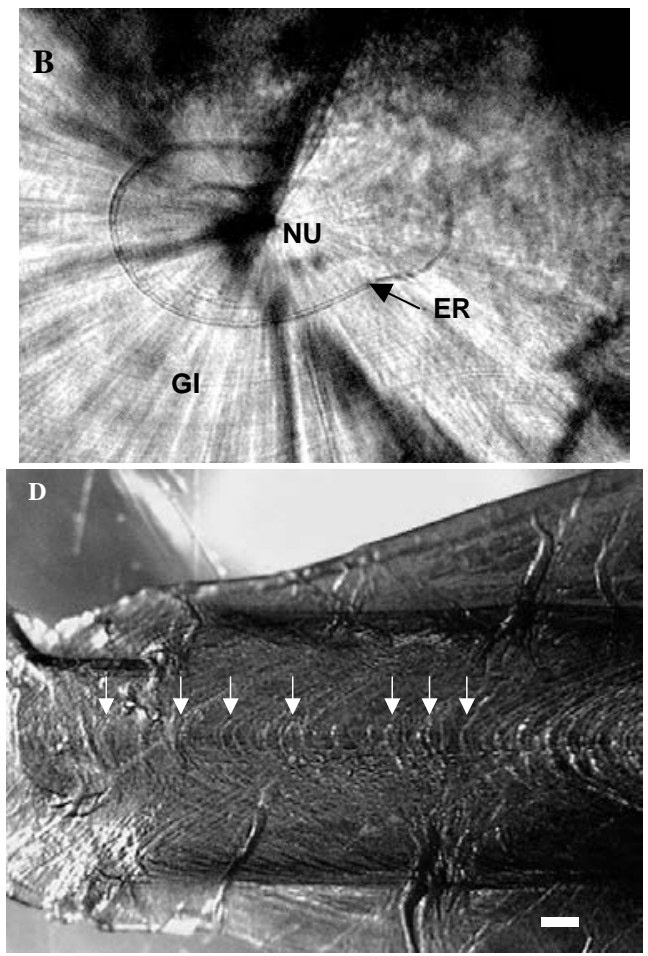

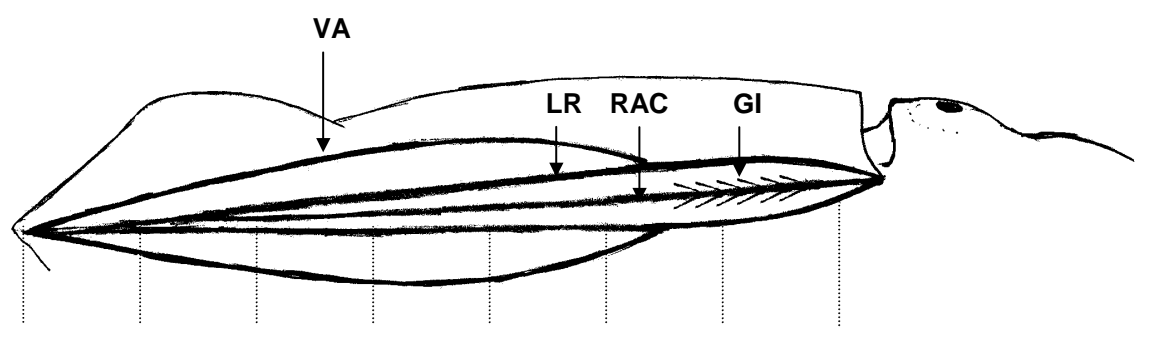

Figure 1 - Morphology and microstructure of Loligo plei statolith and gladius. A, statolith general morphology; B and C, statolith polished surface at 100x magnification, D, gladius plate dorsal surface; E, gladius schematic view. DD, dorsal dome; LD, lateral dome; RA, rostral angle; RO, rostrum; WI, wings; NU, nucleus; ER, eclosion ring; GI, growth increments; SL, statolith length; R, right; L, left; RAC, rachis; VA, vane; LR, lateral ribs; dotted lines, 10 $\mathrm{mm}$ divisions used for increment counting; white arrows indicate visible growth increments; white bar represents $0,5 \mathrm{~mm}$. 


\section{RESULTS}

Statoliths were morphologically characterized by prominent dorsal and lateral domes, which appeared somewhat rounded in juvenile squid. The rostrum, was wide, long (reaching nearly $1 / 3$ of the statolith length) and angulated with the lateral dome (Fig. 1). L. plei statoliths length ranged from 0.97 to $1.96 \mathrm{~mm}$ in males and from 1.20 to 1.90 $\mathrm{mm}$ in females. The relationship between statolith and mantle length was best fitted by a logarithmic model as evidenced by the residuals distribution (Fig. 2).When polished, a nucleus and a series of regular concentric increments, each formed by a pair successive rings (usually one dark and one light as observed by transmitted light), were visible (Fig. 1). A conspicuous ring clearly distinguished around the nucleus (Fig. 1), possibly represented the "eclosion ring" (Natsukari and Komine, 1992).

Rings observed between the eclosion ring and the nucleus were probably embryonic, recording the statolith growth inside the egg (Jackson, 1994). Embryonic rings were $3.2-3.8 \mu \mathrm{m}$ wide, whereas those visible at the upper and lower lateral dome were $4.8-5.0 \mu \mathrm{m}$ and $3.8-4.0 \mu \mathrm{m}$ respectively. A post-nuclear growth zone extended from the eclosion ring towards the statolith border, changing in colour from dark brown to amber (Fig. 1). Increment counts were performed on the dome region, from the embryonic ring towards the statolith border, following the axis of best visibility.

Counts in the three independent occasions were considered consistent, deviating, on average, $4.11 \%$ and $5.55 \%$ of the mean counts according to the APE and CV indices respectively. Similarity between these counts was also evidenced as linear regressions were fitted to each pair of counts and slopes never differed significantly from 1 (Count II $\mathrm{x}$ Count I, slope $=0.90, p$ 0.13; Count III x Count I, slope $=0.86 . p=0.09$; Count III x Count II, slope $=0.90, p=0.25$ ).

B

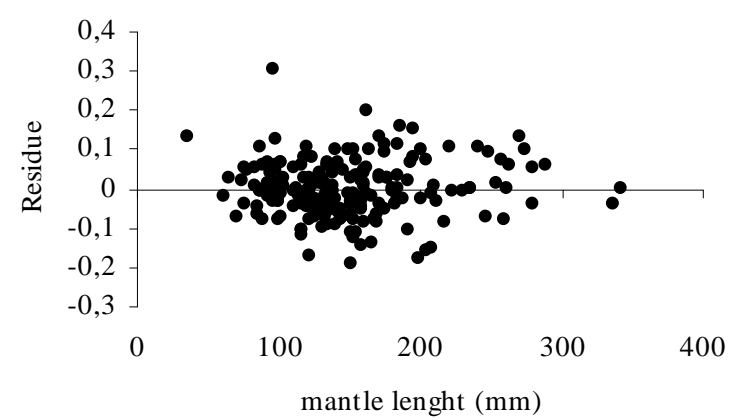

D

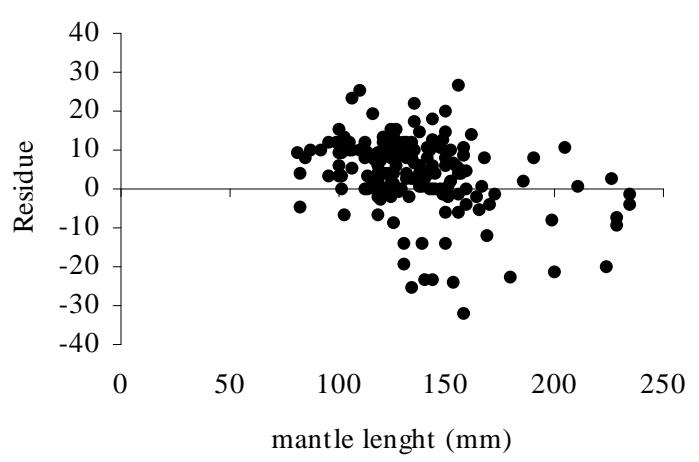

Figure 2 - Relationships between mantle length and statolith length (A, B) and gladius length (C, D). A and C, fitted models; B and D, residuals. 
In $L$. plei, a strong linear correlation was found between ML and GL (Fig. 2) with ML explaining $89.3 \%$ of the total variance of GL. The residual analysis of GL - ML relationship, however, showed that GL of large squid was usually underestimated by the linear model (Fig. 2).

Morphologically the gladius consisted of a wide central rachis with two lateral ribs and long and narrow vanes that inserted the rachis anteriorly forming a concave shoulder (Fig. 1). This plate was mostly formed by the growth of the outer shell layer, the ostracum, and provided the main surface for growth increment interpretation. Unlike the ostracum, the periostracum and hipostracum middle and inner layers respectively were poorly developed in $L$. plei and unsuitable for age and growth studies. The longitudinal growth of the gladius occurred by the deposition of chitin layers to the ventral surface of the ostracum from the fins towards the head (Fig. 1). During low growth periods, these layers crowded together and formed a discontinuous mark that resembled the anterior border of the gladius (seen in both the rachis and the vane shoulders), the interval between consecutive marks corresponding to one growth increment (Fig. 1). The increments observed closer to the gladius border were the ones most recently deposited.

In juvenile and adult squid, growth increments were more clearly observed on the dorsal surface of the rachis. These increments became progressively faint as the rachis narrowed posteriorly and could no longer be distinguished on the posterior end of the gladius. Because early gladius growth was masked, the total number of growth increments were visible, on average, in $79 \%$ of the posterior gladius length. The length of this illegible gladius interval did not vary significantly as a function of the gladius length $(p=0.36)$ (Fig. 3).

Growth increments were enumerated consistently, as shown by the analysis of the precision of growth increment counts in a fixed proportion of the GL. The mean APE calculated for the three independent determinations was $3.4 \%$ and the mean $\mathrm{CV}$ was $4.5 \%$. The number of increments counted per centimetre interval ranged from 5 to 15. The mean spacing between them increased from 0.70 to $1.76 \mathrm{~mm}$ on average in the earliest deposited 20 to $160 \mathrm{~mm}$ GL. In gladii longer than $160 \mathrm{~mm}$, increment variability increased and the mean spacing stabilized between 1.45 and 1.82 mm (Fig. 4).

The rate of gladius and statolith increment deposition was assessed comparing the number increments enumerated in both structures of 98 squids (Fig. 5). A linear relationship with a slope of 1 would be expected gladius if growth increments were deposited at the same rate as statoliths increments. In addition, because gladius counts for each squid included all increments deposited anterior to $70 \mathrm{~mm} \mathrm{GL}$, this assumption predicted that the fitted line should intercept the $y$ axis at a number of statolith increments present in a 70-mm GL squid.

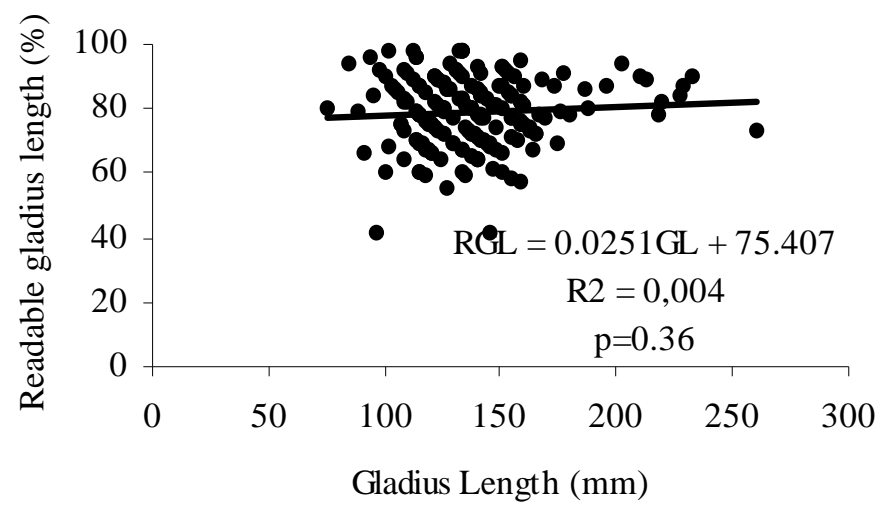

Figure 3 - Variation of the readable length of the gladius plate as a funtion of total gladius length $(\mathrm{mm}) . \mathrm{R}^{2}$, determination coefficient; $p$, probability of the hypothesis $H o$ slope $=0$. 


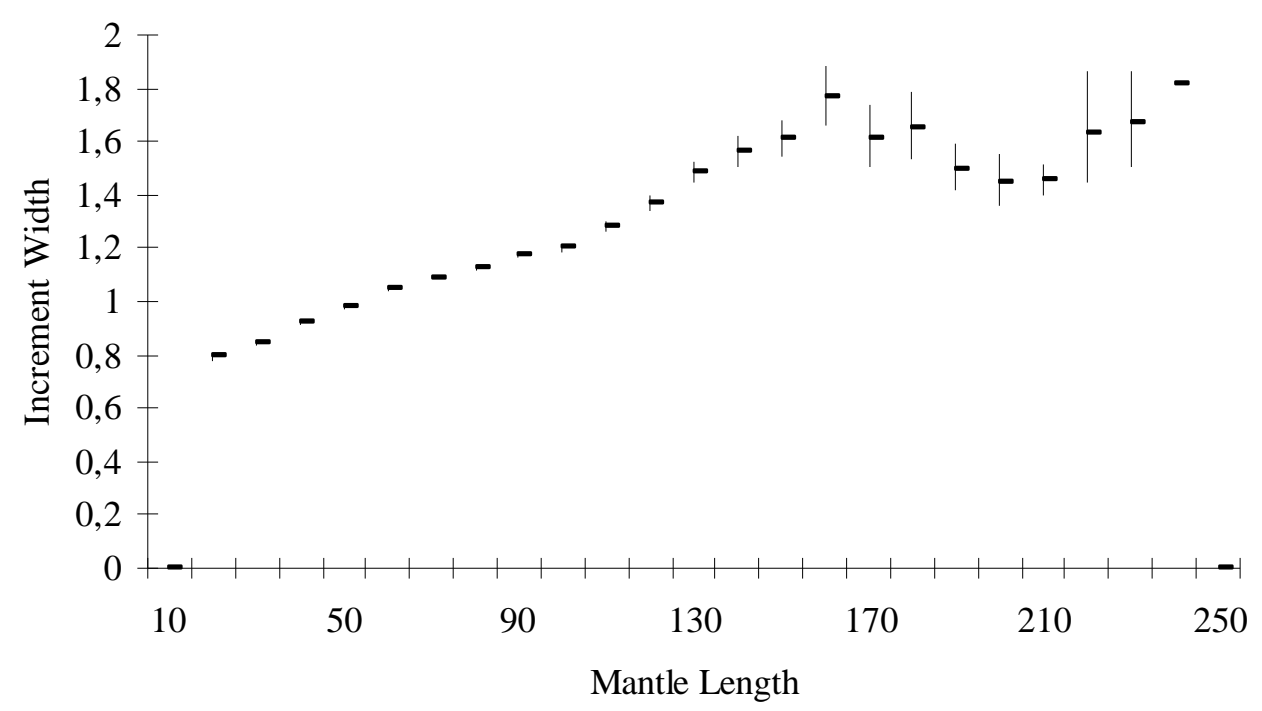

Figure 4 - Size-specific gladius increment width variation $(\mathrm{mm})$. Horizontal and vertical represent means and standard errors calculated for $10 \mathrm{~mm}$ mantle length $(\mathrm{mm})$ respectively.

Statolith and gladius growth increments correlated weakly (Fig. $5, \mathrm{R}^{2}=0.31$ ). However, the slope obtained (0.90) did not differ significantly from the hypothesized slope of 1 ( $\mathrm{p}<0.001)$, and a total of 171.8 statolith increments was estimated by the model for a 70-mm GL squid Statolith mean increment counts obtained for squid from 80 to $230 \mathrm{~mm}$ ML varied from 174.7 to 277.5 (Table 1). Because the total number of increments cannot be enumerated in the gladius structure, total gladius increments were not directly comparable to statolith ones.

However, if a total of 174.7 increments could be hypothesized for gladius $80 \mathrm{~mm}$ long and used to correct gladii counts, more similar numbers could be found for both structures (Table 1).

\section{DISCUSSION}

Statolith and gladius microstructures were investigated for their suitability as tools for age and growth studies in the loliginid squid L. plei off southern Brazil. After proper preparation, both skeletal structures were shown to provide the visualization of reliable increments, which could be enumerated consistently along defined accretion planes. The interpretation of these increment counts as individual age, however, depended on two basic requirements: (a) that the structure's time record included all of the animal's lifetime and (b) the periodicity of increment deposition was known (Campana and Neilson, 1985).

In L. plei statoliths skeletal material deposition is recorded back to embryonic stages indicating that total increment counts could correspond to an individual squid age estimation. Moreover, because validation experiments performed in the Gulf of Mexico confirmed the daily deposition of statolith increments in the species (Jackson and Forsythe, 2002), it can be assumed that total increment counts obtained in squid caught off southern Brazil were approximations of individual age in days.

The gladius structure undergoes structural modifications as ostracum layers are continuously added to the ventral surface of the gladius plate (Perez et al., 1996). Because this process tends to mask part of early deposited growth increments, increment counts underestimate total age. Deposition periodicity, however, seems to parallel that found for statolith increments, which suggest that both structures deposit daily increments. 


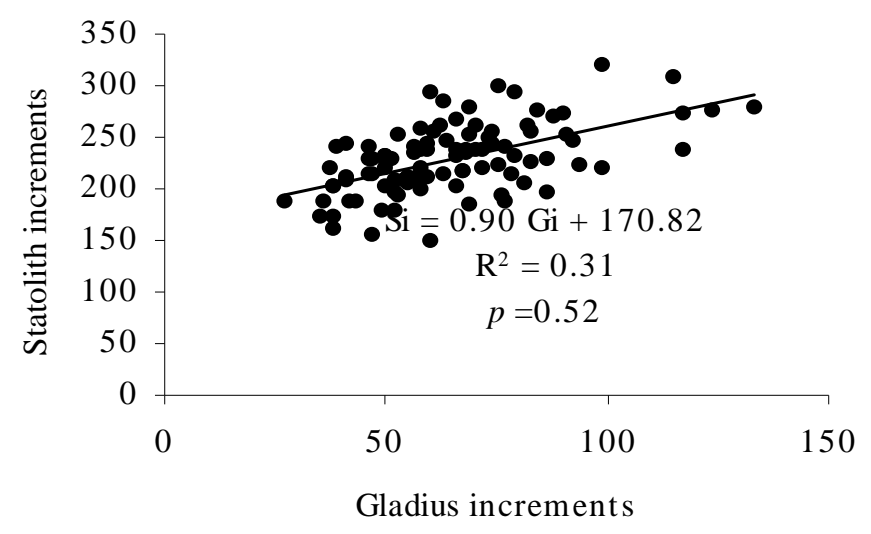

Figure 5 - Relationship between the number of statoltih growth increments and the number of gladius growth increments anterior to $70 \mathrm{~mm}$ GL. $\mathrm{R}^{2}$, determination coefficient; $p$, probability of the hypothesis $H o$ slope $=1$.

Table 1 - Summary of the average of number of increments deposited in statolith and gladius of Loligo plei by intervals of mantle length. * determinations made for L. plei in the Gulf of Mexico (Jackson and Forsythe, 2002)

\begin{tabular}{c|c|c|c|c}
\hline $\begin{array}{c}\text { ML classes } \\
(\mathbf{m m})\end{array}$ & $\begin{array}{c}\text { Statolith } \\
\text { increments }\end{array}$ & Gladius increments & $\begin{array}{c}\text { Corrected } \\
\text { Gladius increments }\end{array}$ & $\begin{array}{c}\text { Statolith } \\
\text { increments * }\end{array}$ \\
\hline 80 & 174.7 & 65.6 & 174.7 & 83.1 \\
90 & 179.2 & 72.2 & 181.3 & 92.1 \\
100 & 187.0 & 77.1 & 186.2 & 100.2 \\
110 & 219.3 & 82.1 & 191.2 & 107.5 \\
120 & 217.3 & 87.7 & 196.8 & 114.1 \\
130 & 227.6 & 90.1 & 199.2 & 120.2 \\
140 & 228.5 & 92.0 & 201.1 & 125.9 \\
150 & 235.1 & 96.9 & 206.0 & 131.1 \\
160 & 243.7 & 103.5 & 212.6 & 136.1 \\
170 & 253.3 & 94.7 & 203.8 & 140.7 \\
180 & 246.4 & 141.3 & 250.4 & 145.0 \\
190 & 280.5 & 136.5 & 245.6 & 149.2 \\
200 & 263.3 & 138.5 & 247.6 & 153.1 \\
210 & 254.3 & 161.0 & 270.1 & 156.8 \\
220 & 259.7 & 139.3 & 248.4 & 160.4 \\
230 & 277.5 & 160.0 & 269.1 & 163.8 \\
\hline
\end{tabular}

Skeletal structures of squids could also be important tools to reconstruct individual growth in previous occasions, provided that the deposition rate of skeletal material was proportional to somatic growth (Campana and Neilson, 1985). In that sense, L. plei gladius showed a strong linear correlation with mantle length, a common measure of somatic growth in cephalopods. Because its length was less variable than ML, GL could be the best linear measurement of size (Kristensen, 1983), and gladius growth increments excellent indicators of size-specific somatic growth (Bizikov, 1991; Arkhpkin and Bizikov, 1991; Jackson et al., 1993; Bizikov, 1995; Perez et al., 1996; Arkhipkin and Perez, 1998). Assuming the gladius increment daily deposition, the structure seemed suitable for reconstructing individual daily growth histories in L. plei, which had recently provided important insights into other squid population ecology (Perez et al., 1996; Perez and O’Dor, 1998; Arkhpkin and Perez, 1998). 
Preliminary age estimates obtained from the interpretation of statolith and gladius structures, have shown that L. plei life span was likely less that one year (large males, $230 \mathrm{~mm}$ ML, were found to be around 9 months old), contradicting previous estimates (Perez et al., 2002). Such pattern was also found in the Gulf of Mexico were, at least during the warm season, a life span as short as five months was estimated for large males (Jackson and Forsythe, 2002). It was found that $L$. plei was likely to show a great plasticity in growth as determined by environmental temperature variation along its wide geographical range. This hypothesis was supported by the lower growth observed off southern Brazil, the southern extreme of the species distribution range in the Atlantic.

Size-dependent growth rates, as reconstructed from gladius increments showed that linear growth, attained by squid larger than $170 \mathrm{~mm}$ ML, was preceded by an exponential growth trajectory that extended through approximately $70 \%$ of the entire life. This size-dependent exponential/linear gladius growth trajectory change was also found in the ommastrphids Illex illecebrosus and Sthenoteuthis oualanensis (Bizikov, 1991; Arkhipkin and Bizikov, 1991; Perez and O'Dor, 1998) and suggested a transition from juvenile to adult life. Such life-style transitions as well as sexual dimorfism and the effect of temperature and food regimes are among the hypothesis about $L$. plei ecology that can be elucidated as a more intense gladius growth reconstruction technique is applied in the future.

\section{ACKNOWLEDGEMENTS}

The authors are indebted to the Itajaí Harbor industrial fishing sampling team (UNIVALI CTTMar). Julio Ricardo Buratto and Uirá Cavalcante Oliveira provided invaluable help during sample processing. The senior author and $\mathbf{J}$. A. T. dos Santos were funded by $\mathrm{CNPq}$ Schollarships (Brazilian Ministry of Science and Technology). D.C. de Aguiar was funded by a Santa Catarina State Government Schollarship.

\section{RESUMO}

Foi avaliada a viabilidade do estatólito e do gladius como ferramentas para estudos de idade e crescimento da lula loliginídea Loligo plei no sul do Brasil. Estatólitos são estruturas calcificadas que, após polimento, revelaram uma serie de incrementos concêntricos depositados em torno de um núcleo. Contagens consistentes desses incrementos cobriram toda a vida do animal e puderam ser consideradas apropriadas para a estimativa de idade desse organismo. O gladius é a concha interna que cresce pela deposição longitudinal de camadas de quitina. Incrementos foram observados na superfície dorsal, delimitados por consecutivas marcas formadas durante períodos de crescimento lento. Ao longo da deposição de quitina o crescimento do início da vida é progressivamente mascarado fazendo com que as contagens de incrementos totais subestimem a idade da lula. Devido ao crescimento do gladius correlacionar-se fortemente com o crescimento somático, os incrementos puderam ser utilizados para a reconstrução do crescimento. Os incrementos do estatólito e do gladius foram depositados com a mesma, possivelmente diária, periodicidade. Infere-se que L. plei no sul do Brasil possa atingir até cerca de 9 meses de vida.

\section{REFERENCES}

Arkhpkin, A. I. and Bizikov, V. A. (1991), A comparative analysis of age and growth estimation using statoliths and gladius in squids. In: Jereb, P.; Ragonese, S. and Boletzki, S. V. (Eds.). Squid age determinations using statoliths. Mazzara del Vallo, Italy: NTR-ITTP Special Publication n. 1. pp. 19-33.

Arkhipkin, A. I. and Perez, J. A. A. (1998), Life-history reconstruction. In: Rodhouse,P. G.; Dawe, E. and O'Dor, R. K. (Eds.). Squid recruitment dynamics. The genus Illex as a model, the commercial Illex species and influences on variability. Rome, Italy: FAO Fishery Technical Paper n. 376. pp. 157-180.

Balgos, M. C. and Pauly, D. (1998), Age and growth of the squid Sepioteuthis lessoniana in N.W. Luzon, Philippines. S. Afr. J. Mar. Sci., 20, 449-452.

Bizikov, V. A. (1991), A new method of squid age determination using the gladius. In: Jereb, P.; Ragonese, S. and Boletzki, S. V. (Eds.). Squid age determinations using statoliths. Mazzara del Vallo, Italy: NTR-ITTP Special Publication n. 1. pp. 39-51. 
Beamish, R. J. and Fournier, D. A. (1981), A method for comparing the precision of a set of age determinations. Can. J. Fish. Aquat. Sci., 38, 982-983.

Bizikov, V. A. (1995), Growth of the squid Sthenoteuthis oualanensis (Lesson, 1830) from a new method based on gladius microstructure. ICES Marine Science Symposium, 199, 445-459.

Boyle, P. R. and Boletzky, S. V. (1996), Cephalopod populations: definition and dynamics. Phill. Trans. $R$. Soc. London B, 351, 985-1002.

Caddy, J. F. (1991), Daily rings on squid statoliths: an opportunity to test standard population models? In: Jereb, P.; Ragonese, S. and Boletzki, S. V. (Eds.). Squid age determinations using statoliths. Mazzara del Vallo, Italy: NTR-ITTP Special Publication n. 1. pp. 53-66.

Campana, S. E. and Neilson, J. D. (1985), Microstructure of fish otoliths. Can. J. Fish. Aquat. Sci., 42, 1014-1032.

Chang, W. Y. B. (1982), A statistical method for evaluating the reproducibility of age determination. Can. J. Fish. Aquat. Sci., 39, 1208-1210.

Collins, M. A.; Boyle, P. R.; Pierce, G. J.; Key, L. N.; Hughes, S. E. and Murphy, J. (1999), Resolution of multiple cohorts in the Loligo forbesi population from the west of Scotland. ICES Journal of Marine Science, 56, 500-509.

Hatfield, D. M. (1991), Post-recruit growth of the Patagonian squid Loligo gahi (D’Orbigny). Bull. Mar. Sci., 49, 349-361.

Jackson, G. D. (1990) Age and growth of the tropical near shore loliginid squid Sepioteuthis lessoniana determined from statolith growth ring analysis. Fish. Bull., 88, 111-118.

Jackson, G. D.; Arlhipkin, A.; Bizikov, V. A. and Hanlon, R. T. (1993), Laboratory and field corroboration of age and growth from statoliths and gladii of the loliginid squid Sepioteuthis lessoniana (Mollusca: Cephalopoda). In: Okutami, T.; O’Dor, K. and Kubodera, T. (Eds.). Recent Advances in Cephalopod Fisheries Biology. Tokyo: Tokay University Press. pp. 189-199.

Jackson, G. D. (1994), Application and future potential of statolith increment analysis in squids and sepiolids. Can. J. Fish. Aquat. Sci., 51, 2612-2625.

Jackson, G. D. and Forsythe, J. W. (2002), Statolith age validation and growth of Loligo plei (Cephalopoda: Loliginidae) in the north-west Gulf of Mexico during spring/summer. J. Mar. Biol. Ass. U.K., 82, 3991/1-2.

Jereb, P.; Ragonese, S. and Boletzki, S. V. (1991), Squid age determination using statoliths. In: International Workshop, 1989, Mazara del Vallo. Proceedings... Mazara del Vallo, Sicily, Italy: Instituto di Tecnologia della Pesca e del Pescato, NTR-ITTP Special Publication n. 1.
Kristensen, T. K. (1983), Gonatus fabricii. In: Boyle, P. R. (Ed.). Cephalopods life cycles: species accounts, London: Academic Press. v. 1. pp. 159-173.

Lipinski, M. (1993), The deposition of statoliths: a working hypothesis. In: Okutami, T.; O'Dor, K. and Kubodera, T. (Eds.). Recent Advances in Cephalopod Fisheries Biology. Tokyo: Tokay University Press. pp. 341-262.

Moreno, A.; Pereira, J.; Arvanitides, C.; Robin, J. P.; Koutsoubas, D.; Perales-Raya, C.; Cunha, M. M.; Balguerias, E. and Denis, V. (2002), Biological variation of Loligo vulgaris (Cephalopoda: Loliginidae) in the eastern Atlantic and Mediterranean). Bull. Mar. Sci., 71, 515-534.

Natsukari, Y. and Komine, N. (1992), Age and growth estimation of the European squid, Loligo vulgaris, based on statolith microstructure. J. Mar. Biol. Ass. U.K., 72, 271-280.

O’Dor, R. K. (1998) Can understanding squid life-history strategies and recruitment improve management? $S$. Afr. J. mar. Sci., 20, 193-206.

Perez, J. A. A.; O’Dor, R. K.; Beck, D. P. C. and Dawe, E. G. (1996), Evaluation of gladius structure for age and growth studies of the short-finned squid Illex illecebrosusi (Teuthoidea: Ommastrephidae). Can. J. Fish. Aquat. Sci., 53, 2837-2846.

Perez, J. A. A. and O'Dor, R. K. (1998), The impact of environmental gradients on the early life inshore migrationof the short-finned squid, Illex illecebrosus. S. Afr. J. Mar. Sci., 20, 293-303.

Perez, J. A. A. (2000), Biomass dynamics of the squid Loligo plei and the development of a small-scale seasonal fishery off southern Brazil. Bull. Mar. Sci., 71, 633-651.

Perez, J. A. A.; Aguiar, D. C. and Oliveira, U. C. (2002), Biology and population dynamics of the longfinned squid Loligo plei (Cephalopoda: Loliginidae) in southern Brazilian waters. Fish. Res., 58, 267-279.

Rodhouse, P. G. and Hatfield, E. M. C. (1990), Age determination in squid using statolith growth increments. Fish. Res., 8, 33-334

Zar, J. H. (1984), Biostatistical Analysis. $2^{\text {nd }}$ ed. Englewood Cliffs, New Jersey: Prentice-Hall Intenational.

Received: May 05, 2005; Revised: December 7, 2005; Accepted: July 17, 2006. 